\title{
IMPLEMENTASI AKAD MUDHARRABAH MUQAYYADAH OFF BALANCE SHEET PADA PERBANKAN SYARIAH
}

\author{
Oleh : \\ Rachmad Rizqy K, Ph.D. \\ Diva Meiza Amanda
}

\begin{abstract}
ABSTRAC
Islamic banks are banks whose activities refer to Islamic law, and in their activities they do not charge interest or pay interest to customers. As a financial institution, the bank's main problem is funds. One of the Islamic operational principles applied in raising public funds is the principle of mudharabah muqayyadah. Mudharabah as a partnership, but the recording of transactions is done on an Off Balance Sheet because the bank does not record it in the bank's balance sheet, but only records it in the administrative account. Called mudharabah because of the profit sharing scheme, muqayyadah because there are restrictions. Basically, the collection of funds is applied to savings and deposit products that use mudharabah contracts. The amount of income received by the owner of the mudharabah fund is part of the income received in cash from the distribution of funds by Islamic banks. Therefore, the funds collected under the mudharabah principle are one of the elements in calculating the profit sharing.
\end{abstract}

Keywords: Mudharabah Muqayyadah Contract, Islamic Bank, Islamic Operational Principles

\section{ABSTRAK}

Bank Syariah merupakan bank yang kegiatannya mengacu pada hukum Islam, dan dalam kegiatannya tidak membebankan bunga maupun tidak membayar bunga kepada nasabah. Sebagai lembaga keuangan masalah Bank yang paling utama adalah dana. Prinsip operasional Islam yang diterapkan dalam penghimpunan dana masyarakat salah satunya yaitu prinsip mudharabah muqayyadah. Mudharabah sebagai sebuah kerjasama, namun pencatatan transaksinya dilakukan secara Off Balance Sheet karena bank tidak mencatat dalam neraca Bank, tetapi hanya di catat dalam rekening administratif saja. Disebut mudharabah karena skemanya bagi hasil, muqayyadah karena ada 
pembatasan. Pada dasarnya penghimpunan dana yang di terapkan pada produk tabungan dan deposito yang menggunakan akad mudharabah. Besarnya pendapatan yang diterima oleh pemilik dana mudharabah merupakan sebagian dari pendapatan yang diterima secara tunai dari penyaluran dana yang dilakukan oleh bank syariah. Oleh karena itu, dana yang di himpun dengan prinsip mudharabah merupakan salah satu unsur dalam melakukan perhitungan bagi hasil.

Kata Kunci : Akad Mudharabah Muqayyadah, Bank Syariah, Prinsip Operasional Islam

\section{PENDAHULUAN}

Pada penegasan judul, menjelaskan pengertian judul skripsi ini agar tidak menimbulkan kesalahan makna. Skripsi ini berjudul "Implementasi Akad Mudharabah Muqayyadah Off Balance Sheet Pada Perbankan Syariah." Untuk itu penulis uraikan secara singkat mengenai judul di atas, yaitu : Implementasi atau pelaksanaan, penerapan adalah pertemuan kedua ini bermaksud mencari bentuk tentang hal yang disepakati dulu

Implementasi yang dimaksud dalam judul ini yaitu Pelaksanaan Akad Mudharabah Muqayyadah off Balance Sheet menurut Fiqh muamalah Pada Bank Syariah Cabang Kotabumi, Kab. Lampung Utara.

Akad (ikatan, keputusan, atau penguatan) atau perjanjian atau kesepakatan atau transaksi dapat diartikan sebagai komitmen yang terbingkai dengan nilai-nilai Syariah. Mudharabah Muqayayadah, yaitu akad mudarabah di mana shahibul mal membatasi jenis usaha, waktu, atau tempat usaha.

Mudharabah Muqayyadah off Balance Sheet, merupakan konsep penyaluran langsung dana mudharabah kepada para pelaksana usahanya. 1 Departemen Pendidikan Nasional, Kamus Besar Bahasa Indonesia Pusat Bahasa, (Jakarta: Gramedia Pustaka Utama, 2011), h. 5292 Ascarya, Akad dan Produk Bank Syariah, (Jakarta: Rajawali Pers, 2015), h. 1703 NuruL Huda dan Mohammad Heykal, Lembaga Keuangan Islam: Tinjauan Teoretis dan Praktis, (Jakarta: Prenadamedia Group, 2010 ), h. 77 Pencatatan transaksinya di Bank Syariah Mandiri dilakukan secara off balance sheet, karena transaksi ini tidak dicatat dalam neraca bank, tetapi hanya dicatat dalam rekening administratif saja

Bank Syariah adalah bank yang beroperasi dengan tidak mengandalkan pada bunga. Bank Islam atau biasa disebut dengan Bank Tanpa Bunga, adalah lembaga keuangan atau perbankan yang operasional dan produknya dikembangkan mengikuti ketentuan-ketentuan syariah Islam, khususnya yang 
menyangkut tata cara bermuamalah secara Islam yang berlandaskan pada AlQur'an dan Hadits Nabi SAW

Fiqh Muamalah adalah hukum yang berkaitan dengan tindakan hukum manusia dalam persoalan-persoalan keduniaan. Misalnya, dalam persoalan jual beli, utang piutang, kerjasama dagang, perserikatan, kerjasana dalam penggarapan tanah, dan sewa-menyewa. 6 Berdasarkan uraian di atas, maka rangkaian kata pada judul dimaksud adalah suatu penerapan akad mudharabah muqayyadah off balance sheet pada Bank Syariah Mandiri menurut Fiqh Muamalah dalam produk Bagi Hasil dengan prinsip Mudharabah muqayyadah off Balance sheet.

Karena pelaksanaan akad mudharabah muqayyadah off balance sheet ini tidak dicatat di dalam neraca Bank, namun dicatat pada neraca khusus diluar itu. Resiko pembiayaan terhadap kegagalan nasabah 4 lbid, h. 935 Muhammad, Manajemen Pembiayaan Bank Syariah, (Yogyakarta:Stim Ykpn, 2016), h. 1056 Mardani, fiqh Ekonomi Syariah, (Jakarta: PT Prenadamedia Group, 2015), h. 2 atau pihak lainnya dalam mengembalikan kewajibannya dan tingkat kesehatan yang mendukung pelaksanaan akad mudharabah muqayyadah off Balance Sheet pada Bank Syariah Mandiri menurut Fiqh Muamalah Cab. Kotabumi, Kab. Lampung Utara. Maka penelitian ini di anggap perlu untuk diteliti lebih dalam.

Bank Syariah adalah bank yang beroperasional dengan tidak mengendalikan pada bunga. Bank Islam atau biasa disebut dengan Bank Tanpa Bunga, adalah lembaga keuangan yang operasional dan produknya dikembangkan berlandasan pada Al-Qur'an dan Hadits Nabi SAW. Bank Syariah adalah lembaga keuangan yang usaha pokoknya memberikan pembiayaan dan jasajasa lainnya dalam lalu lintas pembayaran serta peredaran uang yang pengoprasiannya disesuaikan dengan prinsip syariat Islam. Salah satu bank di Indonesia yang menerapkan prinsip syariah yaitu Bank Syariah Mandiri. Bank Syariah Mandiri merupakan bank yang kegiatannya mengacu pada hukum Islam, dan dalam kegiatannya tidak membebankan bunga maupun tidak membayar bunga kepada nasabah. Imbalan yang diterima oleh bank syariah maupun yang dibayarkan kepada nasabah tergantung dari akadnya Seperti yang diketahui Bank Syariah adalah Bank yang menjalankan kegiatannya berdasarkan prinsip syariah yang harus terbebas dari unsur riba. Sesuai dengan firman Allah mengenai pemahaman riba :

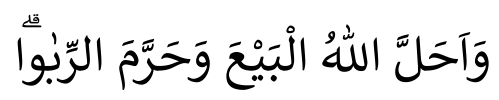

Artinya:

"Allah telah menghalalkan jual beli dan mengharamkan riba." (Q.S Al-Baqarah: 275).

Penggalan ayat diatas menjelaskan mengenai pengharaman riba dalam situasi bisnis ataupun transaksi. Sebagai lembaga keuangan yang menjalankan 
fungsi Bank dengan prinsip Syariah. Layaknya sebuah perusahaan, Bank Syariah Mandiri juga harus bisa menjalankan fungsinya sebagai lembaga perantara dana masyarakat yang menghasilkan profit dengan tidak meninggalkan prinsip Syariah.

\section{Rumusan Masalah}

Berdasarkan uraian dan latar belakang di atas, maka perlu dirumuskan focus permasalahan yang akan dibahas nanti. Adapun yang menjadi permasalahan pokoknya yaitu : "Bagaimana Implementasi akad Mudharabah Muqayyadah off Balance Sheet menurut Fiqh Muamalah".

\section{Tujuan dan Kegunaan Penelitian}

- Tujuan Penelitian

a. Untuk mengetahui Bagaimana pelaksanaan akad Mudharabah muqayyadah off balance sheet pada Bank syariah Mandiri kotabumi.

b. Untuk mengetahui Bagaimana resiko pembiayaan terhadap kegagalan nasabah dalam mengembalikan kewajibannya dan tingkat kesehatan yang mendukung pelaksanaan akad Mudharabah muqayyadah off Balance Sheet pada Bank Syariah Mandiri kotabumi.

c. Untuk mengetahui bagaimana implementasi akad mudharabah muqayyadah off Balance Sheet menurut Fiqh Muamalah.

- Kegunaan Penelitian

a. Penelitian ini diharapkan untuk memberikan wawasan keilmuan bagi penulis dan masyarakat tentang teori dan praktek mengenai akad mudharabah muqayyadah off balance sheet yang sesuai dengan ketentuan Bank Syariah Mandiri.

b. Dapat dijadikan bahan atau sebagai pendorong bagi peneliti-peneliti lain yang bermaksud untuk meneliti permasalahan yang serupa pada lokasi yang berbeda.

\section{PEMBAHASAN}

\section{Akad Mudharabah}

Mudharabah dapat diartikan sebagai akar kerjasama usaha antara dua pihak, yaitu antara pengelola usaha yang disebut sebagai mudharib dan pihak memiliki modal disebut sebagai shahibul maal. Melalui pembiayaan ini, pemberi modal memperoleh bagi hasil secara terus menerus selama usaha masih berjalan. Besar 
keuntungan yang diperoleh dibagi atas dasar kesepakatan yang telah ditentukan di kontrak awal.

- Jenis Mudharabah

Akad mudharabah dibagi menjadi dua jika dilihat dari segi transaksi, yaitu:

1. Mudharabah Mutlaqah: Usaha diajukan oleh mudharib kepada shahibul maal. Dalam akad ini, pemberi modal tidak menentukan jenis usaha apa yang akan dilakukan, dan hanya memberikan modal usaha. Nantinya pemberi modal akan menerima nisbah bagi hasil dari usaha yang berjalan.

2. Mudharabah Muqayyadah: Usaha ditentukan oleh pemberi modal (shahibul maal), sedangkan pihak yang menerima pembiayaan (mudharib) hanya sebagai pengelola yang menjalankan usaha.

- Ketentuan Hukum Mudharabah

1. Mudharabah dapat dibatasi oleh periode tertentu.

2. Kontrak tidak boleh dikaitkan (mu'allaq) dengan sebuah kejadian di masa depan yang belum tentu terjadi.

3. Tidak ada ganti rugi dalam mudharabah, karena akad ini pada dasarnya bersifat amanah. Kecuali akibat dari kesalahan yang disengaja, kelalaian, atau pelanggaran kesepakatan.

4. Jika salah satu pihak tidak memenuhi kewajibannya atau terjadi perselisihan diantara kedua belah pihak, maka penyelesaiannya dilakukan melalui Badan Arbitrasi Syariah jika tidak terselesaikan melalui musyawarah.

\section{Akad Mudharabh Muqayyadah}

Pengertian Akad Mudharabah Muqayyadah menurut istilah syara' mudharabah berarti akad kerjasama antara kedua pihak untuk bekerjasama dalam usaha perdagangan di mana salah satu pihak memberikan dana kepada pihak lain sebagai modal usaha dan keuntungan dari usaha itu akan dibagi diantara mereka berdua sesuai perjanjian yang disepakati. Hasbi Ash-Shiddiqy mengatakan bahwa mudharabah adalah semacam akad, bermufakat dua orang padanya dengan keuntungan, modal dari satu pihak, sedangkan usaha menghasilkan keuntungan dari pihak yang lain, dan keuntungan-keuntungan akan dibagi diantara mereka.

Akad mudharabah adalah perjanjian antara penanam dana dan pengelola dana untuk melakukan kegiatan usaha tertentu, dengan pembagian keuntungan antara kedua belah pihak berdasarkan nisbah yang telah disepakati sebelumnya. 
Apabila rugi, kerugian tersebut ditanggung pemilik modal selama kerugian itu bukan akibat dari kelalaian pengelola. Apabila kerugian diakibatkan kelalaian pengelola, pengelola yang bertanggung jawab. Kewajiban sahibul mal dalam perjanjian mudharabah terbatas (mudharabah muqayyadah) pada kontribusi modalnya. Hal ini merupakan kewajiban dan poin penting dalam perjanjian mudharabah, karena tidak tepat apabila shahibul mal sebagai partner pasif dengan kewajiban tidak terbatas. Mudharib tidak diperkenankan untuk melakukan bisnis lebih dari modal yang disetorkan oleh shahibul Mal. Jika ia melakukan atas kehendak sendiri, dia tidak berhak atas keuntungan dan juga bertanggung jawab terhadap kerugian yang terjadi. Pada dasarnya penghimpunan dana yang di terapkan pada produk tabungan dan deposito yang menggunakan akad mudharabah. Besarnya pendapatan yang diterima oleh pemilik dana mudharabah merupakan sebagian dari pendapatan yang diterima secara tunai dari penyaluran dana yang dilakukan oleh bank syariah. Oleh karena itu, dana yang di himpun dengan prinsip mudharabah merupakan salah satu unsur dalam melakukan perhitungan bagi hasil.

Terdapat 2 (dua) jenis Mudharabah Muqayyadah, yaitu :

1. Mudharabah Muqayyadah yang resiko penempatan dananya ditanggung oleh Bank sebagai executing agent. Dan nasabah terhitung berutang pada bank.

2. Mudharabah Muqayyadah yang resiko penempatan dananya ditanggung oleh pemilik dana, dalam hal ini Bank bertindak sebagai channelling agent. Bank sebagai channelling agent bertindak sebagai perantara. Maka dari itu, bank syariah akan mendapatkan keuntungan seperti upah biaya. Jumlah yang diperoleh oleh bank syariah selalu tetap dan tidak bergantung pada keadaan usaha yang dilakukan. Biaya yang diterima harus dimasukkan dalam laporan laba rugi sebagai pendapatan. Mudharabah Muqayyadah diterapkan untuk tujuan membiayai pembiayaan tertentu yang mempunyai prospektif dan menghasilkan margin yang tinggi atau sesuai dengan permintaan pemilik dana.

Definisi terminologi bagi mudharabah diungkapkan oleh beberapa ulama mazhab sebagai berikut :

a) Menurut Hanafiyah, mudharabah adalah suatu perjanjian untuk berkongsi di dalam keuntungan dan modal dari salah satu pihak dan kerja (usaha) dari pihak lain.

b) Hambali berpendapat bahwa mudharabah adalah penyerahan suatu barang atau sejenisnya dalam jumlah yang jelas dan tentu kepada orang yang mengusahakan dengan mendapatkan bagian tertentu dari keuntungannya.

c) Menurut Sayyid Sabiq, mudharabah adalah akad di antara dua belah pihak di mana salah satu pihak menyerahkan modal kepada yang lain untuk berniaga pada modal tersebut dengan keuntungan dibagi di antara keduanya dengan porsi sesuai hasil kesepakatan. 
d) Sementara Madzhab Malikiyah mendefinisikan mudharabah sebagai penyerahan uang dimuka oleh pemilik modal dalam jumlah yang ditentukan kepada seorang yang akan menjalankan usaha dengan uang itu dengan imbalan sebagian dari keuntungannya. Setelah diketahui beberapa pengertian diatas, dapat disimpulkan bahwa Mudharabah adalah akad antara pemilik modal (Shohibul al-Mal) dengan pengelola usaha (Mudharib), dengan syarat bahwa keuntungan yang di peroleh dari hasil usaha tersebut dibagi berdua sesuai kesepakatan.

Menurut Imam Syafi'i dan Imam Abu Hanafiah, Pembiayaan Mudharabah tersebut diperlakukan seperti akad ijarah I-mitsl. Maka nasabah sebagai pemilik modal (shahibul al-mal) mendapatkan total modal yang pernah diberikan kepada bank sebagai pengelola (mudharib), sedangkan bank sebagai pengelola (mudharib) mendapatkan upah sebesar upah umum (ajr al-mitsl) atas jasanya dalam mengelola usaha. Akad Mudharabah Muqayyadah adalah dimana pemilik dana memberikan batasan kepada pengelola antara lain mengenai dana, lokasi, cara dan sektor usaha. Misalnya, tidak mencampurkan dana yang dimiliki oleh pemilik dana dengan dana lainnya, tidak menginvestasikan dananya pada transaksi penjualan cicilan tanpa penjaminan atau mengharuskan pengelola dana untuk melakukan investasi sendiri tanpa melalui pihak ketiga. Bank dapat bertindak sebagai pemilik maupun pengelola dana, apabila bank bertindak sebagai pemilik dana maka dana yang disalurkan disebut pembiayaan Mudharabah. Apabila Bank sebagai pengelola dana maka dana yang diterima dalam Mudharabah Muqayyadah disajikan dalam laporan perubahan investasi terikat sebagai investasi. Penyerahan modal seseorang kepada pengusaha dengan memberikan batasan, seperti persyaratan bahwa pengusaha harus berdagang di daerah bandung atau harus berdagang sepatu, atau membeli barang dari orang tertentu, dan lain-lain

\section{Dasar Hukum Akad Mudharabah Muqayyadah}

Islam memandang Mudharabah merupakan akad yang dibolehkan berdasarkan Al-Qur'an dan Hadits. Secara umum, landasan dasar syari'ah mudharabah lebih mencerminkan anjuran untuk melakukan usaha. Melakukan mudharabah atau qiradh adalah boleh (mubah). Dasar hukumnya ialah sebuah Ayat Al-Qur'an yang dapat dijadikan sebagai rujukan dasar suatu pembiayaan yaitu Al-Qur'an Surah Al-Maidah, Ayat 1:

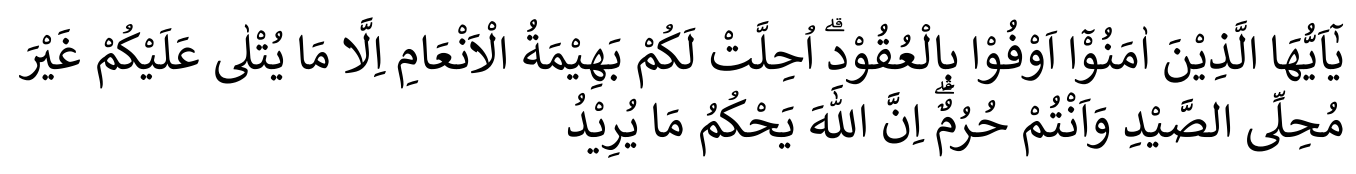


Artinya:

"Hai orang-orang yang beriman, penuhilah akad-akad itu. Dihalalkan bagimu binatang ternak, kecuali yang akan dibacakan kepadamu. (yang demikian itu) dengan tidak menghalalkan berburu ketika kamu sedang mengerjakan haji. Sesungguhnya Allah menetapkan hukum-hukum menurut yang dikehendaki-Nya." (Q.S Al-Maidah: 1 ).

Maksud dari ayat diatas yaitu : akad suatu perjanjian mencakup janji prasetia Hamba kepada Allah dan perjajian yang dibuat oleh manusia dalam pergaulan sesamanya. Ini merupakan perintah Allah kepada Hamba-hambaNya yang mukmin untuk mengerjakan konsekuensi dari pada iman, yaitu memenuhi janji, yakni menyempurnakannya, melengkapinya, tidak membatalkan dan tidak mengurangi. Misalnya, akad antara seseorang dengan yang lain dalam akad mu'amalah, seperti jual beli, menyewa dan sebagainya. Termaksud akad Tabarru'at (kerelaan), seperti hibah dan sebagainya. Bahkan termasuk pula memenuhi hak kaum muslimin yang telah Allah akadkan hak itu diantara mereka, dengan cara tolong menolong diatas kebenaran, membantunya, saling bersikap lembut dan tidak memutuskan hubungan

Rukun dan Syarat Akad Mudharabah Muqayyadah Faktor-faktor yang harus ada (rukun) dalam akad mudharabah adalah :

1) Pelaku (pemilik modal maupun pelaksana usaha) Dalam akad mudharabah harus ada dua pelaku, dimana ada yang bertindak sebagai pemilik modal dan lainnya menjadi pelaksana usaha.

2) Objek mudharabah (modal dan kerja) Objek mudharabah merupakan konsekuensi logis dari tindakan yang dilakukan oleh para pelaku. Pemilik modal menyertakan modalnya sebagai objek mudharabah, sedangkan pelaksana usaha menyerahkan kerjanya sebagai objek mudharabah. Modal yang diserahkan bisa bentuk uang atau barang yang dirinci berapa nilai uangnya. Sedangkan kerja yang diserahkan bisa berbentuk keahlian, ketrampilan, dan lain-lain.

3) Persetujuan kedua belah pihak (ijab-qabul) Persetujan kedua belah pihak, merupakan konsekuensi dari prinsip an-taraddin minkum harus secara rela bersepakat untuk mengikatkan diri dalam akad mudharabah, pemilik dana setuju dengan perannya untuk mengkontribusikan dana, sementara si pelaksana usaha pun setuju dengan perannya untuk mengkontribusikan kerja.

4) Nisbah keuntungan. 
a) Nisbah adalah rukun yang menjadi ciri khusus dalam akad mudharabah. Nisbah ini merupakan imbalan yang berhak diterima oleh shahibul mal ataupun mudharib. Shahibul mal mendapatkan imbalan dari penyertaan modalnya, sedangkan mudharib mendapatkan imbalan dari kerjanya.

b) Perubahan keuntungan harus berdasarkan kesepakatan kedua belah pihak.

c) Pemilik dana tidak boleh meminta pembagian keuntungan dengan menyatakan nilai nominal tertentu karena dapat menimbulkan riba.

Perkara yang membatalkan Mudharabah Muqayyadah Mudharabah dianggap batal apabila ada hal-hal berikut :

a) Pembatalan, Larangan Berusaha, dan pemecatan Mudharabah menjadi batal dengan adanya pembatalan mudharabah, larangan untuk mengusahakan (tasharruf), dan pemecatan. Semua ini jika memenuhi syarat pembatalan dan larangan, yakni orang yang melakukan akad mengetahui pembatalan dan pemecatan tersebut, serta modal telah diserahkan ketika pembatalan atau larangan. Akan tetapi, jika pengusaha tidak mengetahui bahwa mudharabah telah dibatalkan, pengusaha (mudharib) dibolehkan untuk tetap mengusahakannya.

b) Salah seorang Aqid meninggal dunia Jumhur ulama berpendapat bahwa mudharabah batal, jika salah seorang aqid meninggal dunia, baik pemilik modal maupun pengusaha. Hal ini karena mudharabah berhubungan dengan perwakilan yang akan batal.

c) Salah Seorang Aqid Gila Jumhur ulama berpendapat bahwa gila membatalkan mudharabah, sebab gila atau sejenisnya membatalkan keahlian dalam mudharabah.

d) Pemilik Modal Murtad, Apabila pemilik modal murtad (keluar dari Islam) atau terbunuh dalam keadaan murtad, atau bergabung dengan musuh serta telah diputuskan oleh hakim atas pembelotannya, menurut Imam Abu Hanifah, hal itu membatalkan mudharabah sebab bergantung dengan musuh sama saja dengan mati. Hal itu menghilangkan keahlian dalam kepemilikan harta, dengan dalil bahwa harta orang murtad dibagikan di antara para ahli warisnya.

e) Modal Rusak di Tangan Pengusaha, Jika harta rusak sebelum dibelanjakan, mudharabah menjadi batal. Hal ini karena modal harus dipegang oleh pengusaha. Jika modal rusak, mudharabah batal. Begitu pula, mudharabah dianggap rusak jika modal diberikan kepada orang lain atau dihabiskan sehingga tidak tersisa untuk diusahakan.

\section{Pengertian Akad Mudharabah Muqayyadah Off Balance Sheet menurut Fiqh Muamalah}


Menurut Fiqh Muamalah Mudharabah Muqayyadah Off Balance Sheet merupakan konsep penyaluran langsung dana mudharabah kepada para pelaksana usahanya, dengan pembagian menggunakan metode bagi untung dan rugi (profit and loss sharing) atau metode bagi pendapatan antara kedua belah pihak berdasarkan nisbah yang disepakati sebelumnya. Pada Akad Mudharabah Muqayyadah Off Balance Sheet Bank syariah bertindak sebagai arranger dan mendapat fee sebagai arranger, Pencatatan transaksi di Bank Syariah secara Off Balance Sheet, Bagi hasilnya hanya melibatkan nasabah investor dan nasabah pembiayaan. Dasar hukum dibolehkannya Akad ini merupakan yang dikemukakan para ulama fiqh tentang kebolehan bentuk kerjasama ini adalah firman Allah dalam Surah Al-Baqarah ayat 198, yaitu:

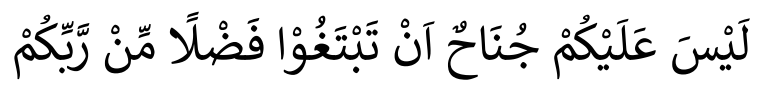

Artinya:

"Tidak ada dosa bagimu untuk mencari kerunia (rezeki hasil perniagaan) dari Tuhanmu."(Q.S Al-Baqarah: 198).

Dari surat Al-Baqarah ayat 198 dapat kita ketahui bahwa untuk mencari karunia Allah dapat dilakukan secara mudharabah dan hukumnya boleh dan sah.

\section{KESIMPULAN}

Berdasarkan uraian pembahasan pada bab-bab sebelumnya, baik dalam bab II tentang landasan teori maupun pada bab III tentang laoparn penelitian "Implementasi Akad Mudharabah Muqayyadah Off Balance Sheet". Maka dapat ditarik kesimpulan sebagai berikut :

1. Pelaksanaan akad Mudharabah Muqayyadah Off Balance Sheet di Bank Syariah dengan tujuan mendapatkan pinjaman dana usaha dengan mengajukan surat permohonan peminjaman dana dengan melengkapi syarat-syarat yang telah diberikan oleh Bank, kemudian pihak Bank menilai sifat atau karakter seorang nasabah, kemampuan nasabah dalam membayar kredit, pekerjaan yang dimiliki nasabah, kondisi ekonomi nasabah, dan jaminan yang diberikan. Sehingga pihak Bank akan mempertimbangkan terlebih dahulu menyetujui atau tidak nasabah meminjam dana tersebut.

2. Resiko pembiayaan disebabkan oleh kegagalan nasabah atau pihak lain dalam mengembalikan kewajibannya. Dengan beberapa faktor, yaitu: karena nasabah sedang sakit, pihak yang bersangkutan meninggal dunia, atau nasabah sedang masa operasi. Yang mempengaruhi Tingkat kesehatan suatu Bank dikarenakan nasabah-nasabah yang aktif dan bertambahnya nasabah baru. 
3. Akad mudharabah Muqayyadah Off Balance Sheet Menurut Fiqh Muamalah hukumnya boleh dan sah, karena sesuai dengan prinsip-prinsip syariah dengan tidak merugikan salah satu pihak.

\section{DAFTAR PUSTAKA}

Abdul Ghafur, Ruslan. 2015, Konstruksi Akad, dalam Jurnal Ak-Kadalah Hukum Islam.

Puji Darma Yanti, 2019, Implementasi Akad Mudharabah Muqayyadah off Balance Sheet pada Bank Syariah Mandiri, Bandar Lampung, Hal iii.

Maskon, 2016, Implementasi Akad Mudharabah Serta Dampaknya Terhadap Produk Penghimpunan Dana di Bank Syariah Bukopin Cabang Semarang, Semarang, Wali Songo, Hal 1.

Fajria Anindya Utami, 2021, Hal 8.

Ascarya, 2013, Akad dan Produk Bank Syariah, Ed-1, Jakarta:Rajawali Pers.

Rianto, Bambang Rustam, 2013, Manajemen Risiko Perbankan Syariah di Indonesia, Jakarta:Salemba Empat.

Muhamad, 2014, Manajemen Dana Bank Syariah, Jakarta, Rajawali Pers. 